\title{
Estimation of Municipal Solid Waste Generation and Future Trends in Greater Metropolitan Regions of Kolkata, India
}

\author{
Swapan Das \\ Department of Mechanical Engineering \\ Bengal Engineering \& Science University, Shibpur, Howrah, India \\ Bidyut Kr. Bhattacharyya \\ Department of Mechanical Engineering \\ Bengal Engineering \& Science University, Shibpur, Howrah, India \\ bidyut53@yahoo.co.in \\ Received 18 March 2014 \\ Accepted 20 September 2014
}

\begin{abstract}
The purpose of this study is to outline the major trends and challenges that will shape the future of waste management for the next few decades in major metropolitan cities like Kolkata. There are certain trends and facts that more or less create the 'bigger picture' in which the waste management industry will evolve. It is clear that new challenges are emerging, and the current situation must be seen in a different way because the disposal site is limited and also it has to be made cost effective. Amounts of waste generation are largely determined by two factors: first, the rate of population increasing in Kolkata metropolitan area and second, its per capita waste generation - which are controlled by the evolution of economic growth, life style and food habits. The present study explains the correlation analysis of among different factors of municipal solid waste and the objective is to assess the future municipal solid waste stream in Kolkata metropolitan area. The results show that for a decoupling to take place between economic growth and waste generation, the waste generation by firms and households in relation to their economic activities must decrease in the future
\end{abstract}

Keywords - existing situation, waste generation, population projection, per capita, estimation.

\section{Introduction}

Municipal solid waste generation is an issue of worldwide concern. The generators of municipal solid waste are broadly classified as residential, industrial, commercial, institutional, construction, demolition, municipal and agricultural types. Municipal solid waste is also generated by human and animal activities that are discarded as useless or unwanted waste. Economic development, urbanization and improving living standard in cities of developing countries have lead to increase in the quantity and complex composition of municipal solid waste. Management of municipal solid waste resulting from rapid urbanization has become a serious concern for government departments, pollution control agencies, regulatory bodies and public in most of the developing countries.

The quantity of MSW generated depends on a number of factors such as food habits, standard of living, degree of commercial activities and seasons. Data on quantity variation and generation are useful in planning for collection, transportation and disposal systems. Kolkata city now generate three times more MSW than they did in 1981 because of increasing urbanization and changing life styles. The rate of increase of MSW generated per capita is estimated at 0.75 to $1.25 \%$ annually. MSW generation rates in small towns are lower than those of metro cities, and the per capita generation rate of MSW in Kolkata $0.35 \mathrm{~kg} /$ day. It was also estimated that the total MSW generated by 14.12 million people living in urban areas was 4837 metric tonne/day in 2013.

\section{Define Project Area}

Kolkata is one of the largest metropolitan cities in India. Till 1912, Kolkata was the capital of India, when the British moved the capital city to Delhi. However, it continued to be the major trade centre and gateway to eastern India. Since independence Kolkata is the capital of the state of West Bengal. The major contributory factors for the growth of the city are political changes and economic transformation. While the Port of Kolkata is India's oldest operating port as well as its sole major riverine port. As of 2011, the city had 4.5 million residents; the urban agglomeration, which comprises the city and its suburbs, was home to approximately 14.1 million, making it the third-most populous metropolitan area in India. As of 2008, its economic output as measured by gross domestic product ranked third among South Asian cities, behind Mumbai and 
Delhi. As a growing metropolitan city in a developing country, Kolkata confronts substantial urban pollution, traffic congestion, poverty, overpopulation, and other logistic and socioeconomic problems. The east-west dimension of the city is comparatively narrow, stretching from the Hooghly River in the west to roughly the Eastern Metropolitan Bypass in the east-a span of 9-10 km. The north-south distance is greater, and its axis is used to section the city (figure 1) into North, Central, and South Kolkata.

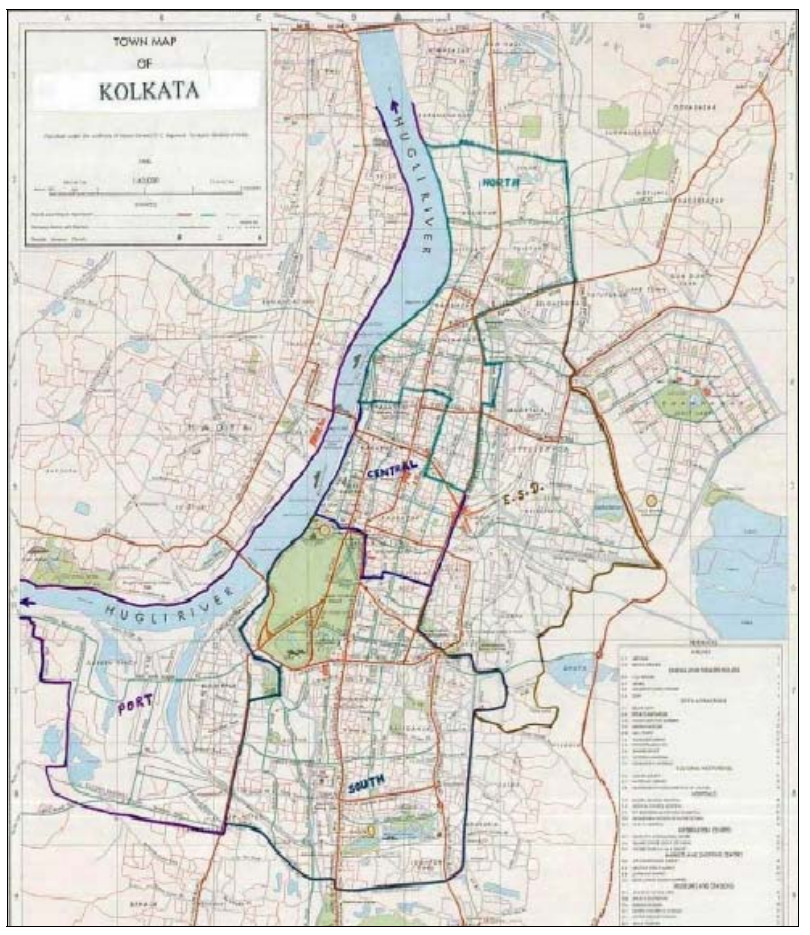

Fig. 1 Map of project area and section of metropolitan city.

\section{Review of Existing Situation}

TABLE I

MUNICIPAL SOLID WASTE GENERATION IN KOLKATA METROPOLITAN CITY DURING SEASON 2013-2014

\begin{tabular}{ccc}
\hline SL NO. & MUNICIPALITY & QUANTITY \\
& & (MT/Day) \\
\hline 1 & Kolkata municipal Corporation (KMC) & 3520 \\
2 & Bidhan Nagar Municipal Corporation (BMC) & 200 \\
3 & Dum Dum Municipality (DDM) & 220 \\
4 & South Dum Dum Municipality (SDDM) & 65 \\
5 & North Dum Dum Municipality (NDDM) & 170 \\
6 & Rajarhat Gopalpur Municipality (RGM) & 260 \\
7 & Baranagar Municipality (BM) & 138 \\
8 & Kamarhati Municipality (KM) & 130 \\
9 & Rajpur Sonarpur Municipality (RSM) & 134 \\
TOTAL & & 4837 \\
\hline
\end{tabular}

Sources: Survey of various municipality corporation areas.

Two Municipality Corporation and seven municipalities cover the whole area of Kolkata metropolitan city. Solid waste management is a statutory function and all Municipal Corporation is responsible for the management of MSW generated in the city. All operations of solid waste management (SWM) in this area are performed under four heads - collection, storage, transportation and disposal. Field surveys were carried out during the financial year 2013-2014 to assess the status of MSW generation in the metropolitan area. Kolkata city generates approximately $4837 \mathrm{MT} /$ day i.e., $0.35 \mathrm{~kg} / \mathrm{cap} / \mathrm{d}$ of MSW. The estimated the quantity of MSW generated from various municipalities in the city, during the year-2013 are shown in table I.

\section{A. Waste Generation Rate from Various Sources}

Major sources of MSW in the metropolitan area are residential areas, commercial or market areas, offices and institutions. Figure 2 shows the percent distribution of solid waste from various sources such as maximum municipal solid waste generate from commercial and market areas around $36.37 \%$, minimum from institutions around $6.32 \%$, household waste generate around $34.20 \%$ and from street sweeping $22.80 \%$ of municipal solid waste.

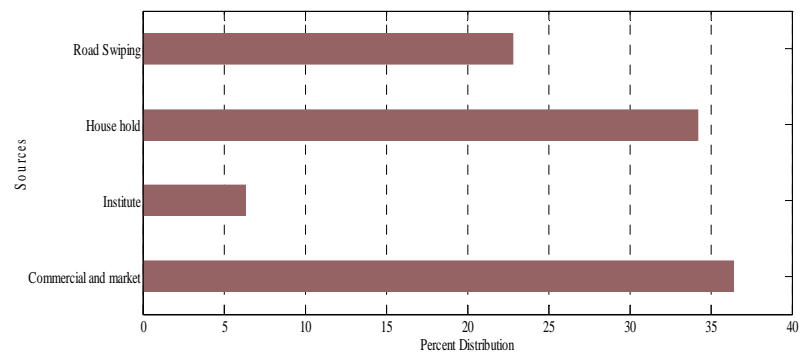

Fig. 2 Percent distribution of municipal solid waste in Kolkata

\section{B. Population Projection}

Developing countries are producing municipal solid waste at an alarming rate. From the last two decades, the amount of municipal solid waste has been increasing rapidly.

TABLE II

POPULATION OF KOLKATA METROPOLITAN CITY (1901-2011)

\begin{tabular}{cccc}
\hline SL NO & YEARS & POPULATION & VARIATION \\
\hline 1. & 1901 & 1510008 & - \\
2. & 1911 & 1745198 & 235190 \\
3. & 1921 & 1884584 & 139386 \\
4. & 1931 & 2138563 & 253979 \\
5. & 1941 & 3621413 & 1482850 \\
6. & 1951 & 4669559 & 1048146 \\
7. & 1961 & 5983669 & 1314110 \\
8. & 1971 & 7420300 & 1436631 \\
9. & 1981 & 9194000 & 1773700 \\
10 & 1991 & 11021900 & 1827900 \\
11. & 2001 & 13114700 & 2092800 \\
12 & 2011 & 14112536 & 997836 \\
\hline
\end{tabular}

Sources: Census of India, Various Issues.

Published by Atlantis Press

Copyright: the authors 
This is particularly due to the rapid growth of urban areas and migration of population from rural to urban areas. Table II presents population of Kolkata during the last century reveal an interesting picture of the development pattern of Kolkata.

In the beginning of the last century Kolkata had more than one million populations; only city in India had the status of metro city. The population of Kolkata increased from 1510008 in 1901 to 14112536 in 2011. The annual growth rate of population in Kolkata during the last century works out to 7.75 per cent. The highest decadal growth of population in Kolkata was observed during 1941-51 at 69.34 per cent and the lowest was in 2001-11 at 7.6 per cent. After 1961 the growth rate of population in Kolkata has been declining. (Figure 3) Growth of population not accompanied by proportionate increase in areas has resulted in increase of density of population in selected locations.

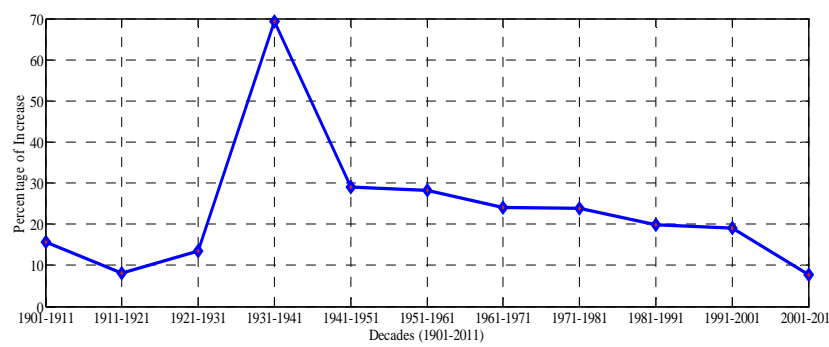

Fig. 3 Percent percentage of population increase in Kolkata

\section{Per Capita Waste Generation Parameters}

Urbanization is now becoming a global phenomenon. Rapid urbanization and uncontrolled growth rate of population accelerate the generation of municipal solid waste. The increasing population directly influences the municipal solid waste generated around the surrounding areas. The socio-economic profile of the population, the consumption patterns govern the characteristics of the waste generated. The industrialization not only influences the quantity of waste but also affects level of urbanization \& increases population levels which results in increase in the overall waste generated.

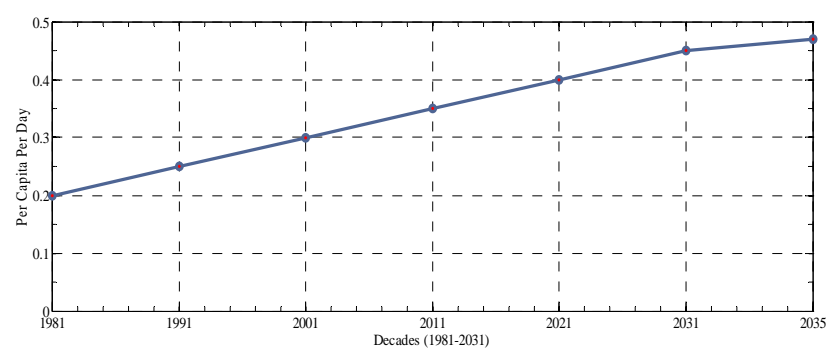

Fig. 4 Per capita waste generation up to design year in Kolkata

In Kolkata, approximately 17.6 lack metric tonnes of waste is generated per year, with per capita values ranging from 0.2 to $6 \mathrm{~kg}$ per person per day and an average of 0.35 $\mathrm{kg} /$ capita/day.

From the above scenario (Figure 4) we can analyse that per capita waste generation is gradually increasing decades to decades and the figure also indicating that average kg per capita per day of waste generated within this region up to design year.

\section{Estimation the Quantity of Waste Generation in Each Year up to Design Year}

Quantity and characteristics of the waste are the major factors, which decide technology to be used for waste disposal. On the basis of the waste quantity, infrastructure requirement can be estimated. It is also necessary to carry out waste analysis frequently in order to assess the changes in waste characteristics due to ever-changing scenario. This data will also serve as a basis for up gradation or switching over to better disposal/treatment option.

\section{A. Forecasting of Municipal Solid Waste Generation}

Storage of waste at source is the first essential step of Solid Waste Management. Every household, shop and establishment generates solid waste on day to day basis. The waste should normally be stored at the source of waste generation till collected for its disposal. In Kolkata, such a habit has not been formed and in the absence of system of storage of waste at source, the waste is thrown on the streets, treating streets as receptacle of waste. Generally no bins for storage of domestic, trade or institutional waste are kept at source.

The future amounts of waste are closely coupled to economic growth given un-changed waste intensities in economic and human activities. Again the waste generation is directly proportional to the rate of change of population. A mathematical calculation is ultra process beginnings with the estimation of future population based on the average increase in population of last two decades and then calculate the future amount of municipal solid waste generation as bellow-

Future population $\left(\mathrm{P}_{\mathrm{f}}\right)=\mathrm{P}_{\mathrm{o}}(1+\mathrm{R} / 100)^{\mathrm{y}}$

Here, $\mathrm{P}_{\mathrm{o}}=$ Initial Population, $\mathrm{R}=$ Percentage of growth rate $=$ $\left\{\left(\mathrm{x}_{1+} \mathrm{X}_{2}\right) / 2\right\} / 10, \mathrm{x}_{1 \&} \mathrm{X}_{2}$ is the population increasing percentage of last two decades and $\mathrm{y}=$ years.

The rate of increasing population is very decades to decades. Here we taken average increasing rate i.e. 20112021 is $13.30 \%$, 2021-2031 is $10.45 \%$ and $2031-2041$ is $11.88 \%$.

Future amount of municipal solid waste generation per day

\section{Quantity $\left(\mathrm{W}_{\mathrm{q}}\right)=\left(\mathrm{P}_{\mathrm{f}}\right) \times\left(\mathrm{w}_{\mathrm{r}}\right) / 1000$}

Here, $\mathrm{P}_{\mathrm{f}}=$ Predicted population, and $\mathrm{w}_{\mathrm{r}}=$ Waste generation rate (kg/capita/day). 
The quantity of municipal waste generation will be in metric tonnes. The future population and waste generation is calculated from the formulation taken 2011 as a base year are shown in table III.

TABLE III

POPULATION AND WASTE GENERATION PROJECTION OF KOLKATA UP TO DESIGN YEAR

\begin{tabular}{cccc}
\hline SL. NO. & YEAR & POPULATION & QUANTITY (MT/DAY) \\
\hline $\mathbf{1}$ & 1981 & 9194000 & 1,839 \\
$\mathbf{2}$ & 1991 & 11021900 & 2,755 \\
$\mathbf{3}$ & 2001 & 13114700 & 3,934 \\
$\mathbf{4}$ & 2011 & 14112536 & 4,939 \\
$\mathbf{5}$ & 2021 & 16105614.85 & 6,442 \\
$\mathbf{6}$ & 2031 & 17870628.33 & 8,042 \\
$\mathbf{7}$ & 2035 & 18734775.4 & 8,805 \\
\hline
\end{tabular}

\section{B. Methodology for Calculating 2035 Projections}

Projections for urban municipal solid waste generation in 2035 were made by factoring expected growth in population and estimated per capita waste generation. The population data collected from census of India as per the report of technical group on population projections constituted by the national commission on population to the office of the Registrar general \& Census commissioner of India. The population projection is calculated by forecasting method. The population growth in Kolkata from 2011 to 2035 shall have a growth of $33 \%$ in 24 years at a rate of $1.4 \%$ of annum. This growth rate is considered in the model from 2011 to 2035 to predict the MSW generation.

The MSW data collected from various municipalities as per the office records and survey work. It is estimated that the amount of waste generated in Kolkata will increase at a per capita rate of approximately $1.4 \%$ annually is considered for estimate of MSW from the year 2011 to 2035. The population versus increase of municipal solid waste generation of year wise from 1981 to 2035 is obtained from forecasting method shown below in figure 5 .

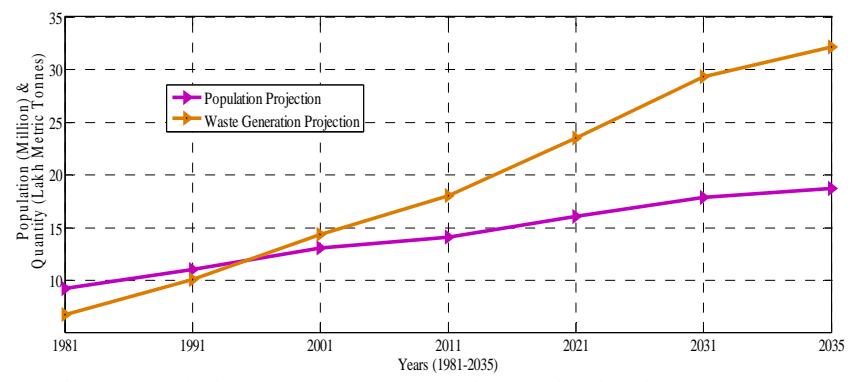

Fig. 5 Population and MSW generation projection in Kolkata

\section{Infrastructure Requirements for Different MSWM}

\section{A. Segregation at Sources}

Separate collection is a vital process in order to make possible the recycling of several materials that are an intrinsic part of municipal solid waste management. Segregation of recyclable waste at source is thus not seriously practiced by households and establishments, who throw such waste on the streets or in the municipal bins unsegregated. At least $15 \%$ of the total waste can conveniently be segregated at source for recycling, which is being thrown on the streets in absence of the practice of segregation of waste at source. In order to encourage the citizens, municipal authority shall organize awareness programmes for segregation of wastes and shall promote recycling or reuse of segregated materials. Different colour bins can be provided for recyclable waste, biodegradable waste and dry solid waste in the cities to segregate waste. But segregation at one point is not enough. It should be followed at all stages. If collected waste is well segregated, then it will be treated well in the end. Segregated recyclable waste, if reused, then quantity of waste can be reduced.

\section{B. Primary Collection}

In most of the area of Kolkata metropolitan cities, waste collection occurs as often as once per day. But areas with a high density of small retail shops, slaughter houses, meat, fish and vegetable markets, hotels, restaurants \& urban areas where storage space is limited, community bins regularly overflows due to heavy dumping of the waste. The frequency of collection and transportation of wastes is not satisfactory in those areas. There is lack of adequate number of containers on each street corner, at several places of densely populated street. The slum and pavement dwellers do not have access to proper services and hence dispose their waste in the public spaces like roads, drains or railway tracks. Hawkers contribute to littering of roads. Community bins are not properly placed or not at a point on the edge of a region which is easy to use \& accessible to both generators and collection vehicles. Waste is dumped around the containers; the messier the site becomes, the fewer people attempt to approach the containers. Often, collection crews are not responsible for picking up waste that is not in the containers so the container site may remain messy and obstructed even after a new container is placed there.

Placing community bins at appropriate locations for deposit and storage of waste is important to manage waste properly. For better MSW management garbage should be lifted frequently from these point sources. Frequency in lifting garbage from these points really matters otherwise garbage pile up \& create other problems. It is challenging task particularly in metros.

Presently 13054 waste collectors are performing waste collection from house to house in Kolkata metropolitan area. A handcart or tricycle are provided to each waste collector to collect the waste from door to door, lanes and by-lanes to load it into the handcart and transfer the same to a secondary collection point in the form of open storage enclosures or dumpers.

\section{Street Sweeping}

Published by Atlantis Press

Copyright: the authors 
Street sweeping is the basic way streets, sidewalks and public areas are kept clean. There are important equity issues in street sweeping, in terms of the amount of municipal resources that go to maintaining cleanliness in various areas. It is common for poor or marginal areas to receive reduced or inadequate service, or no service at all, while wealthier or tourist areas receive extensive service.

Street sweepings are materials such as sand, salt, leaves, broken glass, small pieces of metal, and other litter and debris removed from streets, parking lots and sidewalks in order to prevent these materials from being washed into storm sewers and surface waters, and to improve the appearance and safety of public roadways. Street sweepings are not as clean as virgin earth materials and should be handled with a certain degree of care. Street sweepings usually contain low levels of chemical compounds associated with storm water runoff.

Prior to reuse, materials such as trash, leaves and debris should be removed from the street sweepings by segregation or other appropriate method and such materials should either be disposed of at a permitted solid waste facility, recycled or taken to a composting facility.

An adult man or woman sweeps from two to four kilometres a day in Kolkata. This distance is heavily dependent on type of area, pedestrian education, and frequency of placement of litter containers. Presently 2900 sweeper is performing the road sweeping in Kolkata metropolitan area. A handcart or tricycle, a broom and a scraper are provided to each sweeper to sweep the roads, lanes and by-lanes, to clean open drains, collect the waste, load it into the handcart and transfer the same to a secondary collection point in the form of open storage enclosures or dumpers. Containerized handcarts having four buckets of 40-50 L have been introduced in some wards to transfer waste collected into large containers.

Street sweeping frequency is dependent on type of area and how heavily it is trafficked, and even more heavily on pedestrian education campaigns that address litter- and waste-related behaviour. Such campaigns can have an enormous effect when authorities are willing to persist with them. Frequency and reliability of collection service is also an important factor, as better collection can reduce the need for street sweeping. Similarly, covered trucks allow less litter to be spread by the wind.

\section{Storage of Municipal Solid Waste}

In Kolkata metropolitan area has provided 1028 storage places (in the form of large masonry storage enclosures, trash bins, and dumpers for temporary storage of MSW, which is collected from the city during secondary collection. Large masonry storage enclosures are open spaces enclosed on three sides with a masonry wall of about 1.2-1.8 m height, with capacities ranging from 30 to $60 \mathrm{~m}^{3}$ and located in congested areas with narrow winding streets. Waste is brought to these depots in handcarts during primary collection while trucks can drive into these areas and pickup waste from here for disposal to the landfill site. These large storage enclosures can also be thought of as transfer stations even though they are not formally designed for compaction, nor do they have equipment for separation or processing.

The density of wastes in Indian cities varies from 280 to $660 \mathrm{~kg} / \mathrm{m}^{3}$ while the $\mathrm{KMC}$ estimate is $600 \mathrm{~kg} / \mathrm{m}^{3}$. The available capacity of the storage areas in $\mathrm{KMC}$ is around $23,400 \mathrm{~m}^{3}$. If the density of the waste at the collection point is assumed to be $450 \mathrm{~kg} / \mathrm{m}^{3}$, then the available capacity is more than adequate for a daily collection frequency, which requires a minimum container capacity of $7300 \mathrm{~m}^{3}$. KMC aims to provide daily collection, but overflowing bins are common features throughout the city, despite the excess storage capacity.

Municipal authorities shall establish and maintain storage facilities in such a manner as they do not create unhygienic and unsanitary conditions around it. Storage facilities shall be created and established by taking into account quantities of waste generation in a given area and the population densities. A storage facility shall be so placed that it is accessible to users. Storage facilities or 'bins' shall have 'easy to operate' design for handling, transferring and transportation of waste. Bins for storage of bio-degradable wastes shall be painted green, those for storage of recyclable wastes shall be painted white and those for storage of other wastes shall be painted black. Manual handling of waste shall be prohibited. If unavoidable due to constraints, manual handling shall be carried out under proper precaution with due care for safety of workers.

\section{E. Transport to Transfer Station}

Transfer refers to the movement of waste or materials from collection points to disposal sites. Transportation of waste from collection point to disposal sites is carried out by using different types of vehicles depending on the distances to be covered by them. Larger vehicles carry the waste from the collection points to the disposal sites. Comparatively small vehicles discharge waste at transfer stations where the wastes are loaded into larger vehicles for transportation to the disposal sites. In metro cities transfer stations are located at different places to support intermediate transfer of waste from the surrounding areas up to the dumping grounds.

Transfer stations are centralized facilities where waste is unloaded from smaller collection vehicles and re-loaded into larger vehicles (including in some instances barges or railroads) for transport to a disposal or processing site. The transportation of garbage from the transfer stations is done generally using trailers and bulk refuse carriers.

Vehicles used for transportation of wastes shall be covered. Waste should not be visible to public, nor exposed 
to open environment preventing their scattering. The storage facilities set up by municipal authorities shall be daily attended for clearing of wastes. The bins or containers wherever placed shall be cleaned before they start overflowing. Transportation vehicles shall be so designed that multiple handling of wastes, prior to final disposal, is avoided.

\section{F. Secondary Collection and Transportation}

Secondary waste collection and transportation are stages to optimize waste transportation cost. It consists of lifting of waste after it is collected at the primary level into a community bins and transportation of the same for treatment and disposal. This stage is mostly mechanized involve equipments such as auto tippers, tipper trucks, dumper bins with placers, compactor trucks and bins etc. Routing of transportation vehicles in such a fashion that traffic free portions of the city is used for their movement. Bio-Medical Waste from hospitals, nursing homes, health care establishments etc. to be collected separately and not mixed with the municipal waste.

Presently, mixed waste (biodegradable and recyclable) is collected from residential, commercial and market areas and brought to collection points, which may be small bins or large bulk containers (dumpers) that are painted yellow (42\%) or open storage enclosures (58\%). Waste is directly loaded from these containers into trucks or trailers manually or using pay loaders. This step is known as secondary collection. Pay loaders cannot collect all the waste from the storage enclosures, since some manual cleaning is required. They tend to break the edge of the storage enclosures and that spills waste when loading. Pay loaders also often find it difficult to operate in the narrow cramped streets of Kolkata metropolitan area. Currently, pay loaders are used to collect waste from only $5 \%$ of the total collection points, while the remaining collection is done either manually or by private agencies (mostly manual operations).

Public-private sector partnerships are increasingly becoming the norm in SWM in the country. A recent survey showed that major quantities of municipal solid waste in Kolkata metropolitan area are transported by utilizing private sector agencies for MSWM. More recent estimates show that private agencies are transferring $80 \%$ of the total waste while Municipal Corporation is transferring only $20 \%$.

Twenty days data has been analysed in Dhapa disposal site from 1st July'2013 to 20th July'2013. After the analysis of vehicle entry report we found that at present, there are on average 315 waste collection vehicles - mainly dumperplacer and tipper trucks, out of which 90 are departmental and the rest (225) are hired. For the vat points with greater than a 30 tonne capacity, 13 pay loaders are engaged daily to load wastes into around 17 higher-capacity tipper trucks. On average, 785 trips per day are needed to transfer the municipal solid waste collection point to the disposal site. Out of 785 trip 744 trips for garbage transfer, 37 trips for silt transfer, 3 trips for rubbish transfer and one trip for other materials (Synthetic) transfer.

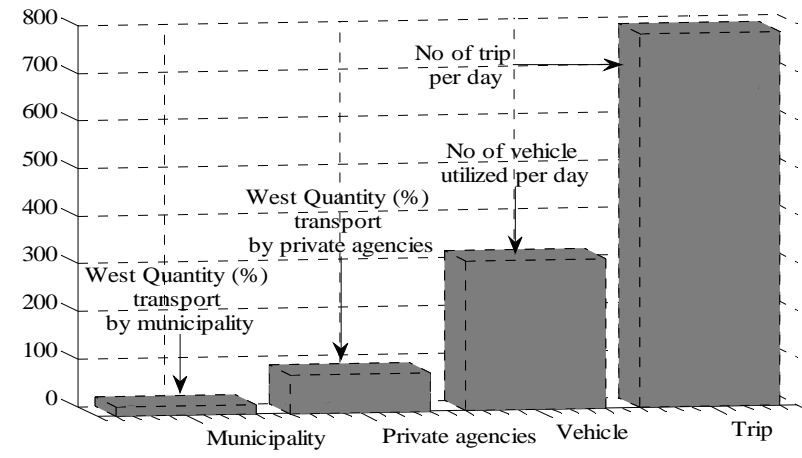

Fig. 6 Municipality and private agencies pertnership in transportaion

\section{G. Processing and Treatment}

Treatability for the processing of solid waste depends on the Physico-chemical characteristics of the waste. Due to nutrient value of organic matter, percentage of biodegradable component in MSW is the most important factor influencing the treatability. Municipal Solid Waste collected from household, market and commercial areas is analyzed recently and the results show that that the waste contains large quantity (48.6\%) of biodegradable components. Further it also contains large quantity of inert matters and sizeable quantity recyclable matter. If silt and debris are not mixed with household and market waste and segregation of recyclable and biodegradable waste at source is adopted, the composting can be carried out efficiently and economically and the waste going to landfill can be reduced by 25 to $30 \%$ and life of the landfill site can be extended saving there by a huge investment on land acquisition.

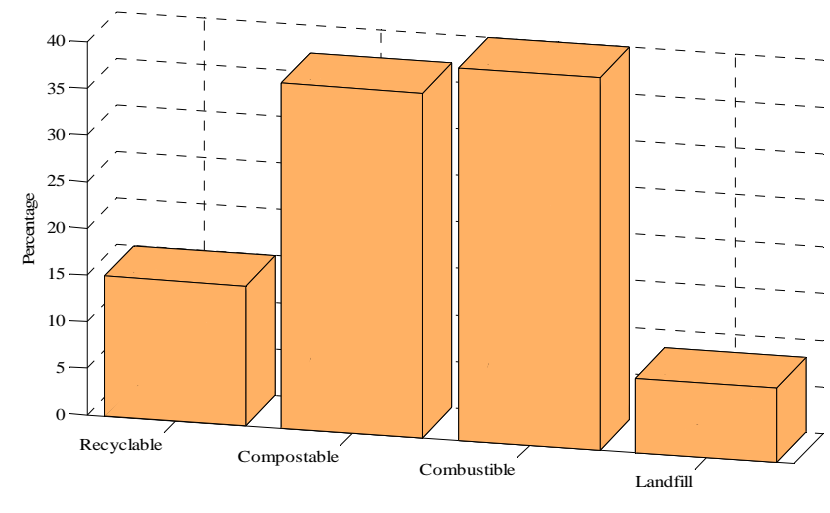

Fig. 7 West materials limitation

The MSW amount for the considered period along with its estimated composition are used directly as inputs to the model to calculate the environmental and economic impacts involved in the integrated west management approach. Having the tonnage of each of the individual waste fractions, the economically feasible upper limits for recycling, 
composting or incineration can be set. These are only indicative of the technical constraints that each waste material imposes (figure 7). These figures will be used in the model as the maximum potential rates that can be achieved within the different waste management scenarios.

\section{H. Disposal of Municipal Solid Waste}

Of all functional elements involved in Solid waste management, Disposal is the most important element as it includes planning, administrative set up, finance, technology support \& their interdisciplinary relationships.

Disposal is referred to the 'different treatments which are given to the waste for avoiding environmental \& health hazards'. Success of Solid Waste Management System is directly related to Disposal efficiency. It is decided upon how much of the total dumped waste is finally disposed properly. To dispose waste in efficient way technology knowledge, trained Manpower, appropriate infrastructure \& availability of land is required.

In Kolkata, the major disposal site of Dhapa is at the eastern fringe of the city at an average distance of $10 \mathrm{~km}$ from the collection points The disposal site property covers 34.2 hectares (ha), of which approximately 21.5 ha consists of waste disposal areas. The site has been divided into an eastern disposal area ("Eastern Mound"), which receives waste from KMC's waste haulers, and a western disposal area ("Western Mound"), which receives waste from private haulers. Bulldozers at the disposal area are used to spread and level the garbage. One $20 \mathrm{t}$ and two $30 \mathrm{t}$ capacity computerized weighbridges serve to check and record the weights. Figure 8 shows per day amount of MSW disposed at the Dhapa landfill site for the period of $1^{\text {st }}$ July'2013 to $20^{\text {th }}$ July'2013. Due to an increase in population, the total waste generation/disposal has increased over the years. Another landfill site exists, and is located in the Garden Reach area of $3.52 \times 104 \mathrm{~m}^{2}$ where approximately 100 metric tonne of wastes are disposed of daily by open dumping.

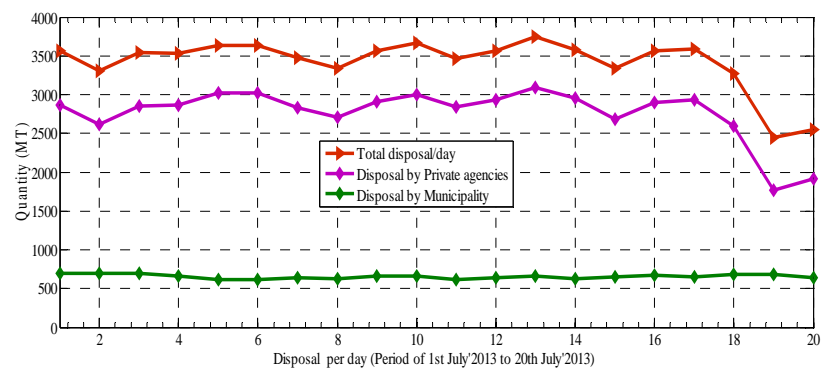

Fig. 8 MSW disposal rate at Dhapa landfill site

In Bidhan Nagar municipality, the disposal site of Muller Bhery is located in sector- $\mathrm{V}$ at an average distance of $5 \mathrm{~km}$ from the collection points. In north Kolkata's municipalities using the common disposal ground located in
Pramodh Nagar area. There is no restriction for nonbiodegradable, inert waste and other waste that are not suitable either environment and pose health risks to the inhabitants. For this reason, the selection of sites where to dispose the waste has to be done scientifically with a number of feasibility studies.

\section{Conclusion}

The scope of future waste generation is here analysed by forecasting method, illustrates the estimates of waste quantum for period from 2011 to 2035 which shows that if the growth of population and the growth of percentage increase in per capita waste generation rate will be increase proportionally. The result shows that the expected municipal solid waste generation by Kolkata metropolitan city in 2035 is 32 lakh metric tonne per year. With rapid development of economy and change of living standard, waste composition is expected to change. For a decoupling to take place between economic growth and waste generation, the waste generation by firms and households in relation to their economic activities must decrease in the future. A number of studies have found that the higher the household income and standard of living, the higher the amount of MSW generated. The per capita waste generation rate is changing decades to decades (0.2 kg/capita in 1981 and $0.47 \mathrm{~kg} /$ capita will be in 2035) due to change of economic growth. In Kolkata, municipal solid waste is still collected without segregation and treatment facilities are also very limited. The proper disposal of municipal solid waste is a necessary step, to minimize the environmental health impacts and degradation of land resources.

The present study also indicated that much larger land areas need to be used for landfill shortage of natural resources such as land because the municipal solid waste generation will be increase. The biodegradable waste can be processed by aerobic composting, vermi -composting, anaerobic digestion or any other appropriate biological processing for stabilization of waste. Regarding municipal solid waste to energy, it should be either thermally treated or biologically treated. The other options are Pyrolysis and Plazma technology which are not cost effective. It is necessary for the success of such technology in Kolkata to evolve and integrated waste management system, coupled with necessary legislative and control measures.

\section{Acknowledgements}

The authors would like to thank the management and staff of Kolkata Municipal Corporation, Bidhan Nagar Municipal Corporation, Dum Dum Municipality, South Dum Dum Municipality, North Dum Dum Municipality, Rajarhat Gopalpur Municipality, Baranagar Municipality, Kamarhati Municipality and Rajpur Sonarpur Muncipality for providing the data used to undertake the research 
outlined in this article. The first author is also like to acknowledge the Deputy Chief Engineer Subhashis Chattapadhay of Kolkata Municipality Corporation to give the permission for visiting the Dhapa landfill site.

\section{References}

[1] S. Chung , K-Y. Winifred Lau, C. Zhang, “ Measuring bulky waste arising in Hong Kong ," Waste Management, vol.30, pp.737-743, year 2010.

[2] A.W. Larsen, H. Merrild, J. Møller, T.H. Christensen, "Waste collection systems for recyclables: An environmental and economic assessment for the municipality of Aarhus (Denmark),” Waste Management, vol.30, pp. 744-754, year 2010

[3] G. Zotos, A. Karagiannidis, S. Zampetoglou, A. Malamakis, I.S. Antonopoulos, S. Kontogianni, G. Tchobanoglous, "Developing a holistic strategy for integrated waste management within municipal planning: Challenges, policies, solutions and perspectives for Hellenic municipalities in the zero-waste, low-cost direction," Waste Management, vol.29, pp.1686-1692, year 2009.

[4] J. P. Su, P.T. Chiueh, M.-L. Hung, H.-W. Ma, "Analyzing policy impact potential for municipal solid waste management decision-making: A case study of Taiwan," Resources, Conservation and Recycling, vol. 51, pp.418-434, year2007.

[5] E. Daskalopoulos , O. Badr, S.D. Probert, "An integrated approach to municipal solid waste management," Resources, Conservation and Recycling, vol.24, pp.33-50, year 1998.

[6] A. Emery, A. Davies, A. Griffiths, K. Williams, "Environmental and economic modelling: A case study of municipal solid waste management scenarios in Wales," Resources, Conservation and Recycling, vol.49, pp.244-263, year 2007.

[7] KEIP (Kolkata Environmental Improvement Project), 2005. Rapid Environmental Impact Assessment Report and Environmental Management Plan of Engineered Landfill at Dhapa. Kolkata Municipal Corporation, India.

[8] R. K. Kaushal, G. K. Varghese, M. Chabukdhara, "Municipal Solid Waste Management in India-Current State and Future Challenges: A Review,” International Jour nal of Engineering Science and Technology, Vol. 4, pp. 1473-1489, year 2012.

[9] A. Khajuria, Y. Yamamoto and T. Morioka, "Estimation of municipal solid waste generation and landfill area in Asian developing countries,” Journal of Environmental Biology, vol. 31, pp. 649-654, year 2010.

[10] L. Sokka, R. Antikainen, P. E. Kauppi, "Municipal solid waste production and composition in Finland-Changes in the period 1960-2002 and prospects until 2020,” Resources, Conservation and Recycling, vol. 5, pp. 475-488, year 2007.

[11] D. C. Nath and D. D. Mwchahary, "Population Increase and Deforestation: A Study in Kokrajhar District of Assam, India," International Journal of Scientific and Research Publications, Vol. 2, pp. 1-12, year 2012.

[12] J. S. Kumar, K. V. Subbaiah, and P. V. V.P. Rao, "Prediction of Municipal Solid Waste with RBF Net Work- A Case Study of Eluru, A.P, India,” International Journal of Innovation, Management and Technology, Vol. 2, pp. 238-242, year 2011.

[13] M.D. Bovea, V. Ibáñez-Forés, A. Gallardo, F.J. ColomerMendoza, "Environmental assessment of alternative municipal solid waste management strategies. A Spanish case study," Waste Management, vol. 30, pp. 2383-2395, year 2010.

[14] N. Kollikkathara, H. Feng, D. Yu, "A system dynamic modeling approach for evaluating municipal solid waste generation, landfill capacity and related cost management issues,” Waste Management, vol. 30, pp. 2194-2203, year 2010.
[15] L. A. Manaf, M. A. A. Samah, N. I. M. Zukki, "Municipal solid waste management in Malaysia: Practices and challenges,” Waste Management, vol. 29, pp. 2902-2906, year 2009.

[16] R. Sha'Ato, S.Y. Aboho, F.O. Oketunde, I.S. Eneji, G. Unazi, S. Agwa, "Survey of solid waste generation and composition in a rapidly growing urban area in Central Nigeria," Waste Management, vol. 27, pp. 352-358, year 2007.

[17] http://censusindia.gov.in/

[18] B. D. Otoniel, M. B. Liliana, P. G. Francelia, "Consumption patterns and household hazardous solid waste generation in an urban settlement in México,” Waste Management, vol. 28, pp. S2S6, year 2008. 